\title{
A Review of Preliminary Experimental Factors of Making Geopolymer Paste as Passive Fire Protection System
}

\author{
Fransisca Maria Farida ${ }^{\mathrm{a}, \mathrm{c},}$, Ananta Sofwan ${ }^{\mathrm{b}}$, Adang Surahman ${ }^{\mathrm{c}}$ \\ ${ }^{a}$ Fire Safety Engineering Department, Universitas Negeri Jakarta, Jl. Rawa Mangun Muka No.1, DKI Jakarta, 13220, Indonesia \\ ${ }^{b}$ P.T. LAPI Institut Teknologi Bandung, Jl. Ganeca No. 15 B, Bandung, 40132, Indonesia \\ ${ }^{c}$ Civil Engineering Department, Institut Teknologi Bandung, Jl. Ganeca No.10, Bandung, 40132, Indonesia
}

Corresponding author: *fransisca_farida@unj.ac.id

\begin{abstract}
Fire can decrease a material's elastic modulus and yield strength due to the creeping process. The use of a passive fire protection system is one strategy to counter this problem. Such a system comprises building materials that can control fires, and this system does not require any special operations in the event of a fire. This paper reviews a new type of passive fire protection systems. It does so through a literature review of preliminary studies on manufacturing new fireproof materials from industrial waste. This is economical and environmentally friendly, and the new materials can overcome the disadvantages of existing fire-resistant material. This study aims to analyze the experimental factors that influence innovative new fireproof material, which can be used for civil engineering. Specifically, the study addresses the geo-polymerization method. It originates from brick manufacturing methods as one of the types of fire-resistant material that exist today. The study provides an overview of the significant factors that influence geopolymer paste's making as a form of passive fire protection. The study found that the determinant factors are the composition ratio between $\mathrm{Si}$ and Al, raw material, alkali type, and water content ratio (w/c).
\end{abstract}

Keywords - Passive fire protection system; geopolymer paste; experimental factor.

Manuscript received 30 Nov. 2017; revised 30 Aug. 2020; accepted 10 Oct. 2020. Date of publication 30 Apr. 2021. IJASEIT is licensed under a Creative Commons Attribution-Share Alike 4.0 International License.

\section{INTRODUCTION}

Fire is a synthetical reaction consisting of fuel, oxygen, and heat. Buildings require effective fire control because uncontrolled fire causes risks for people and can severely damage properties. Three primary goals of fire defense are to limit fire damage of the building structure, allowing occupants to escape from a burning building, and to protect firefighters during rescue operations or when extinguishing fires. Fire protection can be classified into three major systems, namely active fire protection, passive fire protection, and fire safety management. Active fire protection requires action to apply for fire protection, whereas passive fire protection is built-in as part of the building construction. Moreover, fire safety management involves all managerial activities aimed at limiting and putting out fires through manning systems, materials, machines, methods, budget allocation, and information. Fire safety management is commonly regarded as a civilized system. This paper reviews a new fire-resistant material that falls in the category of passive fire protection systems.
Passive fire protection refers to the protection of construction materials [1-6]. It protects against flames, heat, and smoke to deliver fundamental compartmentalization of buildings, structural stability, and separation of the flames. The purpose of this is to ensure people can safely exit a burning building. Passive fire protection systems are built into the building's structure to control fires by using building materials and do not require any special operations in the event of a fire. The purpose of passive fire protection is to protect lives and protect the building from fire and smoke. These goals can be achieved by using openings and barriers, strengthening the building after the fire, minimizing the rebuilding costs, and facilitating business improvement and business continuity in buildings.

Passive fire protection is a solution to handle the effect of fire on a material. For instance, elastic modulus and yield strength decline in burned material due to creeping processes [7]. Materials that experience an increase in temperature display characteristics of glass transition temperature $\left(\mathrm{T}_{\mathrm{g}}\right)$ and yield temperature $\left(\mathrm{T}_{\mathrm{m}}\right)$ variables [8], [9]. Glass transition temperature $\left(\mathrm{T}_{\mathrm{g}}\right)$ is the transition temperature at which material transitions from a solid phase to a rubber phase. 
Meanwhile, yield temperature $\left(\mathrm{T}_{\mathrm{m}}\right)$ is the transition temperature of a material from the rubber phase to a liquid phase. Atoms inside materials that experience temperature increases have large heat energy. These atoms obtain stability by filling in empty places or arranging their position. To overcome changes inside materials as temperature increases, fire-resistant material is used as passive fire protection. Fireresistant building materials available at present are gypsum, brick, stucco, concrete, and intumescent paint.

Current fire-resistant materials have shortcomings [7, 10], namely, the additional insulation material is required. In addition, creating these materials entails a long process. Moreover, existing materials are heavy; they lose strength and experience spalling in a fire. These materials are also not waterproof and have low fire resistance. Furthermore, there is also a need for extensive surface preparation, and these materials decompose to their original composition as they react with carbon dioxide during a fire. This study addresses these shortcomings by introducing a new type of fire-resistant material. The purpose of this review paper is to analyze experimental factors that influence the production of new fireproof material. This innovative fireproof material is useful for civil engineering due to its applicability, while it has fewer disadvantages than existing materials.

This study describes a new method for making bricks based [11], [12] to develop new fire-resistant material. Burning and cementing are the original methods for fire-resistant manufacturing bricks from clay. The disadvantages of both previous methods are the large energy consumption, high $\mathrm{CO}_{2}$ emissions, and shortages of clay as a non-renewable natural resource. In addition to these two methods, geopolymerization is a new method of making bricks that could solve the problems of previous methods. Additional considerations regarding the geo-polymerization method are the use of waste material $[13,14]$.

\section{MATERIAL AND METHOD}

The methodology used in this study is a literature review. It is a preliminary study of the manufacturing of a new type of fireproof material using geo-polymerization. This is an exothermic reaction. In which geo-polymerization reactions are applied at atmospheric pressure and temperatures below $100^{\circ} \mathrm{C}$ [18]. Geopolymer is the regular label of synthetic aluminosilicate material that is made from alkali aluminosilicate with alkali hydroxide/alkali silicate [15-17]. Geopolymers are formed due to a geo-polymerization reaction from amorphous to crystalline $[15,18]$. A specific three-dimensional polymeric structure characterizes these compact amorphous to semi-crystalline solid materials. Besides, geopolymers are amorphous aluminosilicate material [21, 22]. Moreover, geopolymers are a type of inorganic polymers [17-20]. Geopolymers contain macromolecules that are linked by covalent bonds and have an a-Si-O-M-O- backbone in which $\mathrm{M}$ consists primarily of aluminum and secondarily other metals such as iron. Its properties resemble ceramics, which can be produced and hardened at room temperature $[21,22]$.

Material that is used to make geopolymers is classified in different ways. Various studies have divided necessary materials of geopolymer into two types: (1) alumina and silica and (2) alkali [23], [25], [37]. Examples of alumina and silica are fly ash, silica fume, sodium silicate, metakaolin, and Gibbsite. Meanwhile, examples of alkali are caustic soda $(\mathrm{NaOH})$ and potassium hydroxide $(\mathrm{KOH})$ [24]. Other studies discussed geopolymers that consist of aluminosilicate sources such as fly ash, furnace slag and metakaolin [25-36]. Besides, geopolymers are consisting of alkali liquid such as sodium hydroxide and sodium silicate [25]. A separate study described three components to synthesize geopolymers: the raw materials, inactive filler, and geopolymer solution [38]. Examples of basic materials are fly ash, blast furnace slag, red mud, and waste glass. Meanwhile, kaolin or metakaolin is an example of an inactive filler consisting of ion $A l^{3+}$. In addition, geopolymer solutions consist of a sodium silicate liquid and alkali hydroxide solution. Sodium silicate liquid functions as a binder, whereas the alkali hydroxide solution dissolves the raw material. In this study, the raw materials used to make geopolymers are divided into two components: (1) alumina and silica, and (2) alkali. The process of geopolymer formation is described in Fig. 1 [15].

The first step in Figure 1 presents aluminate and silica as the result of the dissolution of solid aluminosilicate, alkaline hydrolysis, and water. This process creates an amorphous solid aluminosilicate. After the formation of aluminate and silica, it becomes a thick supersaturated aluminosilicate. Then, water releases and forms a gel as it produces thick supersaturated aluminosilicate. In the next step of Figure 1, water from this dense supersaturated aluminosilicate formation is managed. Meanwhile, the existing water in the supersaturated aluminosilicate fills the pores of the supersaturated aluminosilicate solution. The type of gel resulting from the formation of the thick supersaturated aluminosilicate is called b-phasic. The process of gel formation causes various gels to connect. The process of polymerization and hardening follows this by forming threedimensional aluminosilicate, which is characteristic of geopolymers.

High-alkaline geopolymers will experience a polymerization process when the active aluminosilicate liquidizes and the free tetrahedral unit $\left(\mathrm{SiO}_{4}\right.$ and $\left.\mathrm{AlO}_{4}\right)$ is released. This is the case for alkali hydroxide and silicate solutions [22], [39], [40], [43]. To form an amorphous geopolymer, the tetrahedral unit binds with precursor polymeric by using oxygen atoms. Positive ions, such as $\mathrm{K}+$ or $\mathrm{Na}+$ appear to compensate for negative ions [15].

The term poly(sialate) stands for silicon-oxo-aluminate at the time of chemical design for the geopolymer aluminosilicate. Poly(sialate) is a chain and ring polymer with $\mathrm{Si}^{4+}$ and $\mathrm{Al}^{3+}$ on 4 -fold coordination with oxygen $[22,30]$. The general formula of poly(sialate) is presented in Equation (1) $[10,41]$ :

$$
\mathrm{Mn}\left[-\left(\mathrm{SiO}_{2}\right) \mathrm{z}-\mathrm{AlO}_{2}\right] \text { n. } \mathrm{wH}_{2} \mathrm{O}
$$

$\mathrm{M}$ is a monovalent cation such as $\mathrm{K}^{+}$or $\mathrm{Na}^{+}$ $\mathrm{n}$ is the degree of polycondensation $\mathrm{z}$ is 1,2 or $>>3$ 


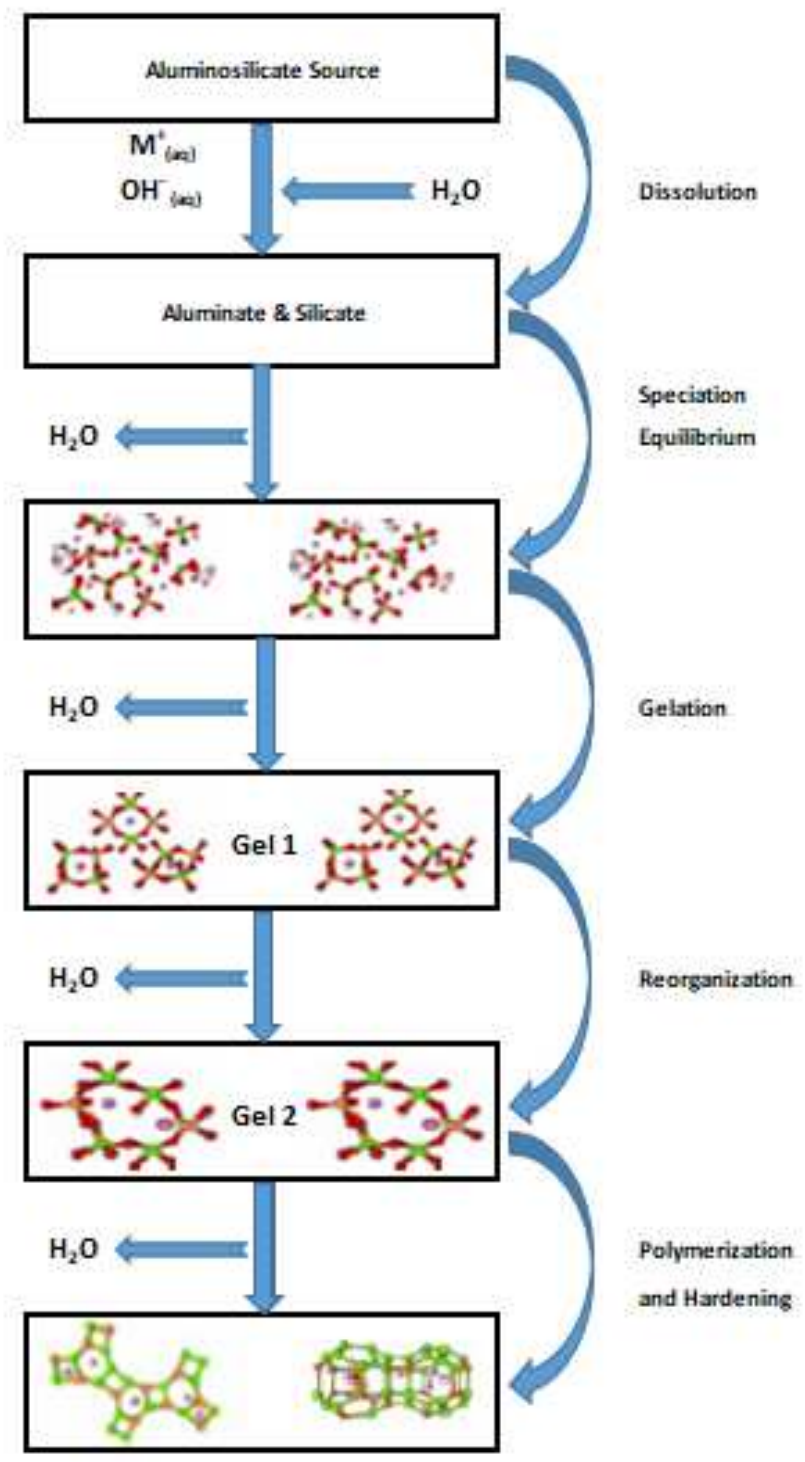

Fig. 1 The process of Geopolymer formation [7]

Sodium $(\mathrm{Na}+)$ and potassium $(\mathrm{K}+)$ can balance the negative charge introduced by $\mathrm{Al}(\mathrm{OH})_{4}^{-1}$ and, thus, the stoichiometric $\mathrm{M} / \mathrm{Al}$ ratio is $1 . \mathrm{Z}$ is the $\mathrm{Si} / \mathrm{Al}$ mole ratio of the structure, ranging between 1 and 15 , and up to 300 [64]. Some sialate (Si-O-Al) forms in the cross-link chain and ring formation. Electron diffraction analysis is a method of studying geopolymer structures [42]. These structures are amorphous to semi-crystalline. The three-dimensional image of the silico-aluminate structure with properties from amorphous to semi-crystalline in [22] and [19] is shown in Fig. 2.

The geo-polymerization process [43] is presented in Equation (2) and Equation (3). Both equations above show that Si-Al material can be a source of geo-polymerization [44]. 16 Al-Si's natural extractives as a potential material resource for producing a geopolymer [43]. This study found that all silica and alumina resources can disperse in alkali solutions. Both of these sources can be used as raw material to form geopolymers [43].

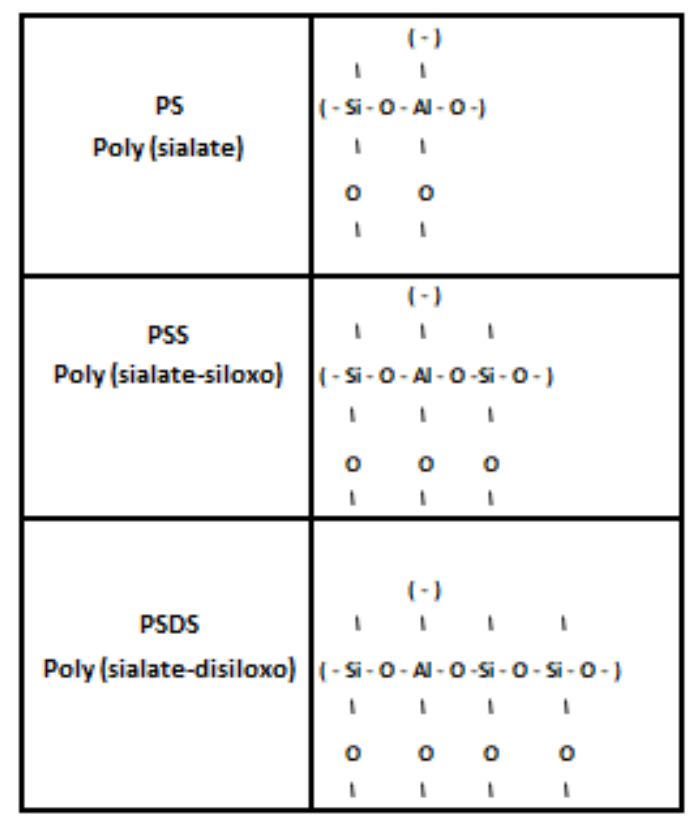

Fig. 2 Geopolymer Terminology [10], [37]

$$
\begin{aligned}
& \mathrm{n}\left(\mathrm{Si}_{2} \mathrm{O}_{3} \mathrm{Al}_{2} \mathrm{O}_{2}\right)+2 \mathrm{nSiO}_{2}+4 \mathrm{nH}_{3} \mathrm{O}+\mathrm{NaOH}_{\mathrm{a}} \text { or }(\mathrm{KOH}) \rightarrow \mathrm{Na}^{+}, \mathrm{K}^{*}+\mathrm{n}(\mathrm{OH})_{3}-\mathrm{Si}-\mathrm{O}-\mathrm{Al}-0-\mathrm{Si}-(\mathrm{OH})_{3} \\
& \text { (Si-Al materials) } \\
& (\mathrm{OH})_{2} \\
& \text { (Geopolymer Precursor) } \\
& \begin{array}{lll}
1 & 1 & 1 \\
0 & 0 & 0
\end{array} \\
& \begin{array}{lll}
1 & 1 & 1 \\
1 & 1 & 1
\end{array}
\end{aligned}
$$

Temperature plays an essential role in the kinetic reaction and mechanical properties of a red mud-class $\mathrm{f}$ fly ash-based geopolymer [39]. This study found that elevated temperature can accelerate the dissolution of raw materials, thereby enhancing geopolymer gels' development. Each of the three stages of geo-polymerization occurred faster at a higher curing temperature, as can be seen from the final setting time and the Si-O-T band shift. The higher geo-polymerization rate is also confirmed qualitatively as the amorphous stage occurred earlier in the $X R D$, and mechanical strength developed faster than at room temperature [39].

Water affects the geo-polymerization of metakaolin [45]. Specifically, the stable distribution of metakaolin geopolymer pore size relies on both water to solid ratio $(\mathrm{w} / \mathrm{s})$ and the $\mathrm{NaOH} /$ metakaolin or $(\mathrm{N} / \mathrm{M})$ ratio. Specifically, the $(\mathrm{w} / \mathrm{s})$ ratio determines the formation of large/macropores. Meanwhile, the $(\mathrm{N} / \mathrm{M})$ ratio affects the creation of small/micropores.

Seven experimental studies of fire-resistant material have been conducted by using geopolymers. The following seven paragraphs will briefly describe these studies. The fire resistance of geopolymer panels was made from granulated blast furnace slag [46]. This study measured physical properties (e.g., density, porosity, and water absorption rate) as well as mechanical properties such as compressive strength and fire resistance. This study found that geopolymers' 
physical and mechanical properties relate to the alkali solution, and the amount of metakaolin added.

The second study assessed the geopolymer's fire resistance for plates made from metakaolin [47]. This study aimed to obtain a composition for a $\mathrm{Na}_{2} \mathrm{O}-\mathrm{Al}_{2} \mathrm{O}_{3}-n \mathrm{SiO}_{2}-\mathrm{mH}_{2} \mathrm{O}$ system and technology to make fire-resistant geopolymers that do not decrease the value of the refractory bloating material factor. The composition $\mathrm{Na}_{2} \mathrm{O} . \mathrm{Al}_{2} \mathrm{O}_{3} .7 \mathrm{SiO}_{2} .23 \mathrm{H}_{2} \mathrm{O}$ has the highest bloating factor. Besides, using an additive in the form of calcium carbonate and sodium tetraborate mixture with sodium bicarbonate will accelerate the rate of hardening and coating attachment without decreasing the bloating factor [47]. The third study assessed geopolymer fire resistance for stainless steel and mild steel made from metakaolin [48]. It focused on the ratio of $\mathrm{Si}$ to $\mathrm{Al}$ for adhesion to stainless steel and mild steel. The study found strong geopolymer adherence with a value of $3.5 \mathrm{MPa}$. This occurs when the ratio $\mathrm{Si}$ to $\mathrm{Al}$ value is $2.5 \mathrm{MPa}$ [48].

Moreover, another study [49] focused on fire resistance of geopolymer made from class f fly ash for metal. Two similar studies have been conducted on geopolymer adherence to materials $[48,49]$. The differences between the studies relate to the material, material characterization, and new research variables. The material used is metakaolin [48], and class f fly ash [49]. The material is characterized by using $X$-ray Diffractometry (XRD) and Scanning Electron Microscopy (SEM) [49]. Meanwhile, another study [50] did not use material characterization. A new variable is water to cement ratio, whereas the variable of ratio $\mathrm{Si}$ to $\mathrm{Al}$ is used [48], [49]. A strong adhesive of more than $3.5 \mathrm{MPa}$ can be obtained for a ratio of Si to $\mathrm{Al}$ of 2.5 for metakaolin and 3.5 for class f fly ash [50].

The fire-resistance of geopolymers made from metakaolin for steel plate [50]. In this study, sodium silicate and sodium hydroxide pellets were added with a $\mathrm{Si}$ to $\mathrm{Al}$ ratio of 3.1 . In addition, three types of the composition of water to cement were added. The three compositions show coating adhesiveness greater than $3.5 \mathrm{MPa}$ tensile stress and high structural integrity with the steel plate of $X R D$ results [50].

The fire resistance of a geopolymer is made from fly ash with coarse and fine vermiculite granules [25]. This study regarding thermal properties $D T A-T G$ and heat addition found that both thermal properties DTA-TG and heat addition depend on the geopolymer's internal structure. The addition of coarse vermiculite granules will improve fire resistance property more than by using fine vermiculate granules [25].

Lastly, the influence of fire on panel pasta geopolymer is made from fly ash, metakaolin, and sodium silicate [51]. The purpose of this study was to obtain physical properties, mechanical properties, as well as fire and environmental resistance. Physical properties include density, water absorption, and porosity, whereas mechanical properties include flexural strength and compressive strength. High fly ash in geopolymers can be used as a fire-resistant plate. Meanwhile, the metakaolin geopolymer has a lower density and higher water absorption than geopolymers without metakaolin. Compared with Portland Cement, a fly ash geopolymer has greater fire resistance and compressive strength. Furthermore, the use of fly ash geopolymer has no negative impact on the environment [51]. These seven studies clearly show the application of geopolymers as fire resistance material.

Various studies have addressed the heat properties of geopolymers. For instance, geopolymer heat transfer has been studied using fly ash and metakaolin as raw material [52]. Geopolymer's heat expansion or shrinkage is measured based on dimension calculation with dilatometry or the ex-situ method. It is essential to know the effect of burning on a geopolymer, precisely its value of enlargement and reduction because prolonged shrinkage or accretion due to fire exposure causes internal and external stress. These stresses could potentially weaken or damage the building structure. Factors that affect heat expansion of geopolymer are water content ratio (w/c), type of raw material, alkali type, and composition ratio [53]. The next section of results and discussion will address the mechanism and assessment of geo-polymerization regarding experimental factors in producing fire resistance from geopolymer paste.

\section{RESULTS AND DISCUSSION}

Geopolymers are liquid mixtures that consolidate at room temperature. They are obtained by the dissolution of an aluminosilicate source in the presence of an alkaline solution. The aluminosilicate source is the main raw material/precursor in the geopolymer process. Meanwhile, the alkaline solution is the second raw material/activator. The geo-polymerization mechanism is initiated by the disintegration of alumina and silica from the raw materials [54]. The split-up of alumina and silica in the geopolymer process has been described briefly in the previous section. Metal/proton exchange reaction, which results from the dissolution of both these materials, causes the initial removal of surface metals such as $\mathrm{Na}^{+}$and $\mathrm{Ca}^{2+}$ [55]. It is the reason that the elimination of surface metals makes $\mathrm{OH}^{-}$ions attack alumina-silicate. The bonds between $\mathrm{AlO}$ are weaker than $\mathrm{SiO}$ bonds [55]. Weak $\mathrm{AlO}$ bonds make Al enter the solution as $\mathrm{Al}(\mathrm{OH})_{4}{ }^{-}$complexes. Meanwhile, disjoined $\mathrm{Si}$-Tetrahedra becomes easier for $\mathrm{OH}^{-}$attack. In addition, there are formations of silicon acids and oligomers that contain $\mathrm{SiO}$ groups, which are often written as $\mathrm{Si}(\mathrm{OH})_{3} \mathrm{O}^{-}$. In solution with alkaline cations, they neutralize the negative charge. Initially, Al is a preferential dissolution, but later, a steady state is reached with the stoichiometric release of $\mathrm{Si}$ and $\mathrm{Al}$ even though the overall dissolution rate seems to decrease due to an increase of $\mathrm{Al}$ in the solution.

The geo-polymerization mechanism is supported by the disintegration rate of feldspars [56]. Contact between disjoined products that have been accumulated between silica and alumina monomers enhances coagulation. This coagulation leads to polycondensation. The resulting aluminosilicate gel oversaturates and settles to form an amorphous product [57], containing a considerable amount of zeolitic phases in the form of nanocrystals, such as sodalite, faujasite, zeolite A, zeolite ZSM-5, and others. The geopolymerization mechanism affects experimental factors such as the composition ratio between $\mathrm{Si}$ and $\mathrm{Al}$, the type of basic material, alkali type, and water content ratio (w/c) [52].

It is important to consider the composition ratio between $\mathrm{Si}$ and $\mathrm{Al}$ in the geo-polymerization process [43, 44]. The composition ratio between $\mathrm{Si}$ and $\mathrm{Al}$ depends on the geopolymerization mechanism. The atom numbers of $\mathrm{Si}$ and $\mathrm{Al}$ are 14 and 13, respectively, whereas Si has 4 outer electrons, 
and $\mathrm{Al}$ has 3 outer electrons. The bonds between $\mathrm{AlO}$ are weaker than $\mathrm{SiO}$ bonds [55]. Thus, a higher ratio of $\mathrm{Si}$ to $\mathrm{Al}$ of geopolymer leads to more significant heat expansion than would be the case for a lower Si to Al ratio. Besides the composition ratio, the geo-polymerization mechanism also explains why the type of raw material and the alkali type can affect the geopolymer's heat expansion. The next two paragraphs will describe the effect of the kind of raw material and alkali type in the geo-polymerization mechanism.

As mentioned in the previous section, fly ash, slag, silica fume, sodium silicate, metakaolin, and gibbsite are raw material sources for geopolymers rich in alumina-silica. Table 1, Table 2, Table 3 and Table 4 present the chemical composition of fly ash, slag, metakaolin, and natural zeolite, respectively. Table 5 presents more than one chemical composition of raw material for geopolymers. The percentage of $\mathrm{SiO}_{2}$ and $\mathrm{Al}_{2} \mathrm{O}_{3}$ from each raw material of geopolymer influences its heat expansion. Specifically, a higher percentage of $\mathrm{SiO}_{2}$ than $\mathrm{Al}_{2} \mathrm{O}_{3}$ causes more significant heat expansion of geopolymers. This is because the bonds between $\mathrm{AlO}$ are weaker than $\mathrm{SiO}$ bonds.

TABLE I

FLy ASH CHEMICAL COMPOSITION OF GEOPOLYMER BASIC MATERIAL

\begin{tabular}{lllll}
\hline No. & Basic Material & $\mathbf{S i O}_{\mathbf{2}}(\mathbf{\%})$ & $\mathbf{A l}_{\mathbf{2}} \mathbf{O}_{\mathbf{3}}(\mathbf{\%})$ & Study \\
\hline 1 & Class f fly ash & 49.88 & 24.80 & {$[25]$} \\
2 & Class f fly ash & 52.20 & 20.10 & {$[37]$} \\
3 & Class f fly ash & 46.36 & 37.60 & {$[49]$} \\
4 & Fly ash & 10.22 & 4.18 & {$[58]$} \\
5 & Pulverized fly ash & 46.80 & 23.70 & {$[59]$} \\
6 & Class f fly ash & 65.5 & 26.7 & {$[60]$} \\
7 & Class f fly ash & 43.34 & 20.60 & {$[61]$} \\
\hline
\end{tabular}

TABLE II

SLAG ChemiCAL COMPOSITION OF GEOPOLYMER BASIC MATERIAL

\begin{tabular}{lllll}
\hline No. & Basic Material & $\mathbf{S i O}_{\mathbf{2}}(\%)$ & $\mathbf{A l}_{\mathbf{2}} \mathbf{O}_{\mathbf{3}}(\%)$ & Study \\
\hline 1 & FeNi slag & 41.14 & 13.79 & {$[17]$} \\
2 & Blast furnace slag & 35.95 & 10.01 & {$[62]$} \\
3 & Ferrochrome slag & 33.80 & 25.48 & {$[49]$} \\
4 & FeNi slag & 41.14 & 13.79 & {$[64]$} \\
5 & Blast furnace slag & 37.30 & 13.10 & {$[65]$} \\
6 & Slag & 36.00 & 11.00 & {$[66]$} \\
\hline
\end{tabular}

TABLE III

Metakaolin ChEMiCAL COMPOSITION OF GEOPOLYMER BASIC MATERIAL

\begin{tabular}{lllll}
\hline No. & Basic Material & $\mathbf{S i O}_{\mathbf{2}}(\mathbf{\%})$ & $\mathbf{A l}_{\mathbf{2}} \mathbf{O}_{\mathbf{3}}(\%)$ & Study \\
\hline 1 & Metakaolin & 52.26 & 42.83 & {$[46]$} \\
2 & Metakaolin & 46.36 & 37.60 & {$[47]$} \\
3 & Metakaolin & 46.36 & 37.60 & {$[48]$} \\
4 & Metakaolin & 46.36 & 37.60 & {$[50]$} \\
5 & Metakaolin & 51.35 & 44.24 & {$[67]$} \\
6 & Metakaolin & 52.90 & 41.90 & {$[68]$} \\
7 & Metakaolin & 53.00 & 43.80 & {$[69]$} \\
\hline
\end{tabular}

TABLE IV

NAtural ZeOlite ChemicAl COMPOSITION OF GEOPOLYMER BASIC MATERIAL

\begin{tabular}{lllll}
\hline No. & Basic Material & $\mathbf{S i O}_{2}(\mathbf{\%})$ & $\mathbf{A l}_{2} \mathbf{O}_{3}(\%)$ & Study \\
\hline 1 & Natural Zeolite & 62.74 & 9.68 & {$[54]$} \\
2 & Silica Chlorosilane & 84.23 & 4.18 & {$[81]$} \\
3 & Na13X Zeolite & 55.21 & 4.79 & {$[82]$} \\
& Powder & & & \\
4 & Na13X Zeolite & 55.21 & 4.79 & {$[85]$} \\
& Powder & & & \\
\hline
\end{tabular}

TABLE V

MORE THAN ONE CHEMICAL COMPOSITION OF GEOPOLYMER BASIC MATERIAL

\begin{tabular}{|c|c|c|c|c|}
\hline No. & Basic Material & $\mathrm{SiO}_{2}(\%)$ & $\mathrm{Al}_{2} \mathrm{O}_{3}(\%)$ & Study \\
\hline 1 & $\begin{array}{l}\text { Granulated Blast } \\
\text { Furnace Slag }\end{array}$ & 34.39 & 14.47 & [46] \\
\hline 2 & Metakaolin & 52.26 & 42.83 & {$[46]$} \\
\hline 3 & Class f Fly Ash & 65.12 & 19.27 & {$[51]$} \\
\hline 4 & Metakaolin & 65.17 & 32.02 & {$[51]$} \\
\hline 5 & Metakaolin & 51.17 & 45.89 & {$[58]$} \\
\hline 6 & Fly Ash & 10.22 & 4.18 & {$[58]$} \\
\hline 7 & Class f Fly Ash & 45.30 & 41.20 & {$[67]$} \\
\hline 8 & Metakaolin & 51.35 & 44.24 & {$[67]$} \\
\hline 9 & Rice Husk Ash & 96.03 & $\begin{array}{l}\text { Not } \\
\text { detected }\end{array}$ & {$[70]$} \\
\hline 10 & Slag & 35.21 & 13.09 & {$[70]$} \\
\hline 11 & Fly ash & 72.10 & 24.70 & [71] \\
\hline 12 & Slag & 33.30 & 14.60 & {$[71]$} \\
\hline 13 & Fly Ash & 29.47 & 51.72 & {$[72]$} \\
\hline 14 & Metakaolin & 53.32 & 42.09 & {$[72]$} \\
\hline 15 & $\begin{array}{l}\text { Fly Ash } \\
\text { (Gaston) }\end{array}$ & 50.38 & 27.20 & {$[73]$} \\
\hline 16 & $\begin{array}{l}\text { Fly Ash } \\
\text { (Orlando) }\end{array}$ & 54.48 & 27.72 & {$[73]$} \\
\hline 17 & $\begin{array}{l}\text { Fly Ash (Martin } \\
\text { Lake) }\end{array}$ & 54.88 & 19.31 & {$[73]$} \\
\hline 18 & Fly Ash (Miller) & 36.23 & 19.41 & [73] \\
\hline 19 & $\begin{array}{l}\text { Fly Ash (Port } \\
\text { Augusta) }\end{array}$ & 24.53 & 11.14 & [74] \\
\hline 20 & $\begin{array}{l}\text { Fly Ash } \\
\text { (Eraring) }\end{array}$ & 45.03 & 7.67 & {$[74]$} \\
\hline 21 & $\begin{array}{l}\text { Fly Ash } \\
\text { (Tarong) }\end{array}$ & 42.79 & 4.11 & [74] \\
\hline 22 & Fly Ash & 51.78 & 27.80 & {$[75]$} \\
\hline 23 & Bauxite & 3.40 & 53.12 & {$[75]$} \\
\hline 24 & Fly ash & 57 & 21 & [83] \\
\hline 25 & Slag & 32.4 & 11.5 & [83] \\
\hline 26 & Fly ash & 57 & 21 & {$[84]$} \\
\hline 27 & Slag & 32.4 & 11.5 & [84] \\
\hline
\end{tabular}

Various studies have been conducted on different alkali types $[23,25,37,76]$. The alkali types used in these studies are sodium $(\mathrm{Na})$ and potassium $(\mathrm{K})$. The atomic numbers of sodium $(\mathrm{Na})$ and potassium $(\mathrm{K})$ are 11 and 19 , respectively whereas the atomic mass of sodium $(\mathrm{Na})$ and potassium $(\mathrm{K})$ is 22.990 and 39.098 , respectively [54, 77]. Potassium $(\mathrm{K})$ is heavier than sodium $(\mathrm{Na})$ and the density (mass per volume) of potassium $(\mathrm{K})$ is greater than that of sodium $(\mathrm{Na})$. This difference in density between sodium $(\mathrm{Na})$ and potassium $(\mathrm{K})$ influences the results of the geo-polymerization. Specifically, 
sodium $(\mathrm{Na})$ dissolves silica and alumina more rapidly than potassium (K) [26]. Moreover, the use of potassium (K) leads to greater strength than sodium $(\mathrm{Na})[42,43,53,76]$. Another benefit of potassium $(\mathrm{K})$ is that it can deliver greater compressive strength of geopolymer than sodium (Na) [53]. Furthermore, a study of the correlation between different levels of moisture content on the rupture force found that water content ratio $(\mathrm{w} / \mathrm{c})$ influences the workability and strength of a material [78].

\section{CONCLUSION}

Thermal problems in buildings relate to the materials used for construction, with or without air spaces. Materials affect the flow of heat too, from, or within substances. Heat flow occurs due to temperature differences which have the potential to drive heat from hotter to colder zones. Burning materials experience a reduction in yield stress and elastic modulus. In order to tackle this reduction, materials need fire protection. Three primary fire safety goals are to limit fire damage to the structure, safeguard occupants from injury until they reach a safe place, and to safeguard firefighters while performing rescue operations or extinguishing fires.

The fire protection system can be categorized into three major systems namely the active fire protection system, passive fire protection, and fire safety management. Active fire protection is an energized system for installed fire protection whereas passive fire protection refers to built-in systems. Fire safety management implies all types of managerial activities aimed at preventing and extinguishing fires through manning systems, materials, machines, methods, budget allocation, and information. Fire safety management is commonly regarded as human systems. This study addressed a passive fire protection system by describing a new fire resistance material.

Current fire resistance materials are gypsum, stucco, concrete, intumescent paint, and brick. These materials have shortcomings as they require additional insulation material. In addition, creating these materials entails a long process. Moreover, existing materials are heavy, they lose strength and experience spalling in a fire. They are also not waterproof and have low fire resistance. Furthermore, there is also a need for extensive surface preparation, and these materials decompose to their original composition as they react with carbon dioxide during a fire. This paper proposes a new fire-resistant material by making bricks. Conventional methods of brick making are by burning and cementing. Two drawbacks of these conventional methods are high energy consumption (approximately $2 \mathrm{kWh} /$ brick and $0,30 \mathrm{kWh} / \mathrm{kg}$ ), and high pollution that is caused by $\mathrm{CO}_{2}\left( \pm 0,41 \mathrm{~kg} \mathrm{CO}_{2}\right)$. In order to address the shortcomings of conventional methods, a new method called geo-polymerization emerged.

This geo-polymerization process involves materials that contain aluminosilicate synthesized from materials containing Alumina $\left(\mathrm{Al}_{2} \mathrm{O}_{3}\right)$ and Silica $\left(\mathrm{SiO}_{2}\right)$. These materials are found in industrial waste/waste materials such as fly ash, slag, silica fume, and metakaolin. In general, this waste material has low calcium content and has high levels of alumina $\left(\mathrm{Al}_{2} \mathrm{O}_{3}\right)$ and Silica $\left(\mathrm{SiO}_{2}\right)$.

Factors that affect the manufacturing of new fire-resistant material with a geo-polymerization's method are composition ratio, type of raw material, alkali type, and water content ratio (w/c). The composition ratio between $\mathrm{Si}$ and $\mathrm{Al}$ depends on the geo-polymerization mechanism. The atom numbers of $\mathrm{Si}$ and $\mathrm{Al}$ are 14 and 13, respectively. Consequently, Si has 4 outer electrons, and $\mathrm{Al}$ has 3 outer electrons. The bonds between $\mathrm{AlO}$ are weaker than $\mathrm{SiO}$ bonds.

Geopolymer resources need to be rich in alumina and silica. The percentage of $\mathrm{SiO}_{2}$ and $\mathrm{Al}_{2} \mathrm{O}_{3}$ from each raw material influences the geopolymer's heat expansion. Specifically, a higher percentage of $\mathrm{SiO}_{2}$ compared to $\mathrm{Al}_{2} \mathrm{O}_{3}$ in raw material leads to higher heat expansion of the geopolymer [79, 80]. This happens because of the bonds between $\mathrm{AlO}$ are weaker than $\mathrm{SiO}$ bonds. Geopolymer raw materials need an alkaline activator solution to have binding property. This solution activates the aluminum $(\mathrm{Al})$ and silica $(\mathrm{Si})$ components so that polymerization bonds occur. The alkaline activator solutions that can be used are those containing Group 1A alkaline elements of the periodic table.

The alkali types used in these studies that this paper reviewed are sodium $(\mathrm{Na})$ and potassium $(\mathrm{K})$. The atomic numbers of sodium $(\mathrm{Na})$ and potassium $(\mathrm{K})$ are 11 and 19 , respectively, whereas their atomic mass is 22.990 and 39.098, respectively $[54,77]$. Potassium $(\mathrm{K})$ is heavier than sodium (Na) and has a greater density. This difference in density influences the resulting geopolymer. Moreover, the water content ratio influences the workability and strength of a material. In this study, the composition ratio between silica (Si) and aluminum (Al) to make fire-resistant geopolymers is between 2 and 35. In order to obtain the composition ratio between silica ( $\mathrm{Si}$ ) and aluminum (Al) and to optimize the usefulness of basic material, several studies have been executed by combining one or more basic material and using one or more basic material with zeolite.

\section{REFERENCES}

[1] Mroz, K., Hager, I., Korniejenko, K., "Materials solutions for passive fire protection of buildings and structures and their performances testing”, Procedia Engineering, vol. 151, pp. 284-291, Aug. 2016.

[2] Said, M., Faizal, M., "The effect of fire retardant composition on burning path and determination of thermal resistance of sawdust for building insulation", International Journal on Advanced Science Engineering Information Technology, vol. 7(4), pp. 1134-1140, ISSN 2088-5334, http://dx.doi.org/10.18517/ijaseit.7.4.2288, 2017.

[3] Elyaries, G. M., "Thermal performance assessment of shipping container architecture in hot and humid climates", International Journal on Advanced Science Engineering Information Technology, vol. 7(4), pp. 1114-1126, ISSN 2088-5334, http://dx.doi.org/10.18517/ijaseit.7.4.2235, 2017.

[4] Wang, F., Wang, M., Huo, J., "The effects of passive fire protection layer on the behaviour of concrete tunnel linings: A field fire testing study", Tunneling and Underground Space Technology, vol. 69, pp. 162-170, 2017.

[5] Bezas, M. Z., Nikolaidis, Th. N., Singh, N. B., "Fire protection and sustainability of structural steel buildings with double-shell brickwork cladding", Procedia Environmental Sciences, vol. 38, pp. 298-305, 2017

[6] Peng, X., Xu, Y., Xu, Z., Wu, D., Li, D., "Effect of simulated radionuclide strontium on geo-polymerizations process", Procedia Environmental Sciences, vol. 31, pp. 325-329, 2016

[7] Buchanan., Structural design for fire safety, John Wiley, and Sons LTD, Chichester, 2009.

[8] Strong, A.B., Plastics: materials and processing, ed. 3, Pearson Prentice Hall, New Jersey, 2006.

[9] Groover, M.P., Fundamentals of modern manufacturing: materials, processes and systems, ed. 3, John Wiley \& Sons Inc., USA, 2013.

[10] Temujin, J., Rickard, W., Lee, M., Riessen, A. V., "Preparation and thermal properties of fire resistant metakaolin-based geopolymer-type coatings," Journal of non-crystalline solids, vol. 357, pp. 1399-1404, Mar. 2011. 
[11] Zhang, I., "Production of bricks from waste materials-a review," Construction and building material, vol. 47, pp. 643-655, Oct. 2013.

[12] Monteiro, S. N. and Vieira, C. M.F., "On the production of fired clay bricks from waste materials: a critical update," Construction and building material, vol. 68, pp.599-610, Oct. 2014.

[13] Afrah, B. D., Sajjakulnukit, B., Bustan, M.D., "Product competitiveness of upgrading brown coal (UBC) process in Indonesia", International Journal on Advanced Science Engineering Information Technology, vol. 7(4), pp. 1289-1295, ISSN 2088-5334, http://dx.doi.org/10.18517/ijaseit.7.4.2488, 2017.

[14] Nurhadi, N., Efendi, M. A. A., Rianda, S., "The utilisation of fixed bed coal gasification by-products to produce combustible gas by autothermal process", International Journal on Advanced Science Engineering Information Technology, vol. 7(5), pp. 1964-1969, ISSN 2088-5334, http://dx.doi.org/10.18517/ijaseit.7.5.2104, 2017.

[15] Duxson, P., Jimenez, A. F., Provis, J. L., Lukey, G. C., Palomo, A., Van Deventer, J. S. J., "Geopolymer technology: the current state of the art", Journal Material Science, vol. 42, pp. 2917-2933, May 2007.

[16] Cheng, H., Lin, K. L., Cui, R., Hwang C. L., Cheng T. W., Chang, Y. M., "Effect of solid-to liquid ratios on the properties of waste catalystmetakaolin based geopolymers," Construction and Building Materials, vol. 88, pp. 74-83, July 2015.

[17] Sakkas, K., Panias, D., Nomikos, P. P., Sofianos, A. I., "Potassium based geopolymer for passive fire protection of concrete tunnels linings", Tunnelling and Underground Space Technology, vol. 43, pp. 148-156, June 2014

[18] Van Deventer, J.G.S., Van Deventer, J.S.J., Lukey, G.C., "The effect of composition and temperature on the properties of fly ash-and kaolinite-based geopolymers", Chem. Eng. J., vol. 89, pp. 63-73, Oct. 2002.

[19] Davidovits, J., 1988, Geopolymer Chemistry and Properties. In: Davidovits, J., Orlinsky, J. (Eds.), Proceedings of Geopolymer ' 88 , Compiegne, pp. 25-88.

[20] Davidovits, J., 1999, "Chemistry of geopolymeric systems terminology", In: Proceedings of the 2nd International Conference on Geopolymer '99, terminology, In: Proceedings of the 2nd International Conference on Geopolymer '99, 1999, pp. 9-39.

[21] Bakharev, T., "Resistance of geopolymer materials to acid attack", Cement and Concrete Research, vol. 35, pp. 658-670, Apr. 2005.

[22] Komnitsas, K.A., "Potential of geopolymer technology towards green buildings and sustainable cities", Procedia Engineering, vol. 21, pp. 1023-1032, https://doi.org/10.1016/j.proeng.2011.11.2108, 2011

[23] McLellan, B. C., Williams, R. P., Lay, J., Riessen, A.V., Corder, G. D., "Costs and carbon emissions for geopolymer pastes in comparison to ordinary Portland cement", Journal of Cleaner Production, vol. 19, pp. 1080-1090, July 2011

[24] Hosan, A., Haque, S., Shaikh, F., "Compressive behaviour of sodium and potassium activators synthesised fly ash geopolymer at elevated temperatures: a comparative study", Journal of building engineering, vol. 8, pp. 123-130, 2016

[25] Temuujin, J., Minjigmaa, A., Rickard, W., "Thermal properties of spray-coated geopolymer-type composition”, Journal of Thermal Anal. Calorim., vol. 107, pp. 287-292, July 2011.

[26] Saadi, T. H. A., Badanoiu, A. L., Nicoara, A. L., Stoleriu, S., Voicu, G., "Synthesis and properties of alkali-activated borosilicate inorganic polymers based on waste glass", Construction and Building Materials, vol. 136, pp. 298-306, 2017

[27] Zawrah, M. F., Gado, R. A., Feltin, N., Ducourtieux, S., Devoille, L. "Recycling and utilisation assessment of waste fired clay bricks (grogs) with granulated blast-furnace slag for geopolymer production", Process Safety and Environmental Protection, vol. 103, pp. 237-251, 2016

[28] Saavedra, W. G. V., Mejia de Guetierrez, R., "Performance of geopolymer concrete composed of fly ash after exposure to elevated temperatures", Construction and building materials, vol. 154, pp. 229235, 2017

[29] Luga, E., Atis, C. D., "Optimisation of heat-cured fly ash/slag blend geopolymer mortars designed by "combined design" method: part 1", Construction and building materials, vol. 178, pp. 393-404, 2018

[30] Niklioc, I., Markovic, S., Jankovic-Castvan, I., Radmilovic, V. V., Karanovic, Lj., Babic, B., Radmilovic, V. R., "Modification of mechanical and thermal properties of fly ash-based geopolymer by the incorporation of steel slag", Materials Letters, vol. 176, pp. 301-305, 2016

[31] Fan, F., Liu, Z., Xu, G., Peng, H., Cai, C. S., "Mechanical and thermal properties of fly ash-based geopolymers", Construction and building materials, vol. 160, pp. 66-81, 2018
[32] Nath, S. K., "Geo-polymerisation behavior of ferrochrome slag and fly ash blends," Construction and building materials, vol. 181, pp. 487494, 2018

[33] Yang, T., Wu, Q., Zhu, H., Zhang, Z., "Geopolymer with improved thermal stability by incorporating high-magnesium nickel slag," Construction and building materials, vol. 155, pp. 475-484, 2017

[34] Toniolo, N., Boccaccini, A. R., "Fly ash-based geopolymer containing added silicate waste. A review," Ceramics International, vol. 43, pp. $14545-14551,2017$

[35] Saxena, S. K., Kumar, M., Singh, N. B., "Fire-resistant properties of aluminosilicate geopolymer cement mortars," Materials today: proceedings, vol. 4, pp. 5605-5612, 2017

[36] Assi, L. N., Deaver, E. E., Ziehl, P., "Effect of source and particle size distribution on the mechanical and microstructural properties of flyash based geopolymer concrete," Construction and building materials, vol. 167, pp. 372-380, 2018

[37] Allison, P. G., Weiss Jr, C. A., Moser, R. D., Diaz, A. J., Rivera, O.G., Holton, S. S., "Nanoindentation and sem/edx characterisation of the geopolymer-to-steel interfacial transition zone for a reactive porcelain enamel coating," Composites Part B, vol. 78, pp. 131-137, March 2015.

[38] Ikeda, K., "Consolidation of mineral powders by the geopolymer binder technique for materials use," Journal of the Mining and Materials Processing Institute of Japan, vol. 114, pp. 497-500, 1998.

[39] Zhang, M., Zhao, M., Zhang, G., Sietins, J. M., Granados-Focil, S., Pepi, M. S., Xu, Y., Tao, M., "Reaction kinetics of red-mud-fly ashbased geopolymers: Effects of curing temperature on chemical bonding, porosity, and mechanical strength", Cement and concrete composites, vol. 93, pp. 175-185, 2018

[40] Wang, Y. S., Dai, J. G., Ding, Z., Xu, W. T., "Phosphate-based geoplymer: formation mechanism and thermal stability," Materials Letters, vol. 190, pp. 209-212, 2017

[41] Sabbatini, A., Vidal, L., Pettinari, C., Sobrados, I., Rossignol, S., "Control of shaping and thermal resistance of metakaolin-based geopolymers," Materials and design, vol. 116, pp. 374-385, Dec. 2016

[42] Van Jaarsveld, J. G. S., Van Deventer, J.S.J, Schwartzman, A. "The potential use of geopolymeric materials to immobilise toxic metals: part II. material and leaching characteristics," Mineral Engineering, vol. 12(1), pp. 75-91, Jan. 1999.

[43] Xu, H. dan Deventer, J.S.J.V., "The geopolymerisation of aluminosilicate minerals," International Journal Mineral Process, vol. 59, pp. 247-266, June 2000

[44] Van Jaarsveld, J. G. S., Van Deventer, J.S.J, Lorenzen, L., "The potential use of geopolymeric materials to immobilise toxic metals: part I. theory and applications," Mineral Engineering, vol. 10(7), pp. 659-669, July 1997.

[45] Park, S., Pour-Ghaz, M., "What is the role of water in the geopolymerizations of metakaolin?" Construction and building materials vol. 182 , pp. $360-370,2018$

[46] Cheng, T., W. dan Chiu, J. P., "Fire-resistant geopolymer produced by granulated blast furnace slag", Minerals Engineering, vol. 16, pp. 205210, Dec. 2002.

[47] Krivenko, P. V., Pushkareva, Ye. K., Sukhanevich, M. V., Guziy, S. G., "Fireproof coatings on the basis of alkaline aluminium silicate systems, development in strategic materials", in Ceramic Engineering Science Proceeding, paper 29.10, p. 129-142, Jan 2009.

[48] Temuujin, J., Minjigmss, A., Rickard, W., Lee, M., Williams, L., Riessen, A. V., "Preparation of metakaolin based geopolymer coatings on metal substrates as thermal barriers", Applied Clay Science, vol. 46, pp. 265-270, Aug. 2009.

[49] Temuujin, J., Minjigmaa, A., Rickard, W., Lee, M., Williams, L., Riessen, A. V., "Fly ash-based geopolymer thin coatings on metal substrates and its thermal evaluation", Journal of Hazardous Materials, vol. 180, pp. 748-752, May 2010.

[50] Temuujin, J., Rickard, W., Lee, M., Riessen, A. V., "Preparation and thermal properties of fire resistant metakaolin-based geopolymer-type coatings", Journal of non-crystalline solids, vol. 357, pp. 1399-1404, Oct. 2010.

[51] Luna-Galiano, Y., Cornejo, A., Leiva, C., Vilches, L.F., FernandezPereira, C., "Properties of fly ash and metakaolin based geopolymer panels under fire resistance test", Materiales de construccion, vol. 65(319), pp. 59, Sept. 2015

[52] Riessen, A. V., Rickard, W., Sanjaya, J., 15-Thermal properties of geopolymer, Ser. Woodhead Publishing in Civil and Structural Engineering, Woodhead Publishing, 2009, pp. 315-342.

[53] Xu, H., Deventer, J.S.J.V., Lukey, G.C., "Effect of alkali metal on the preferential geo-polymerisation of stilbitc/ kaolinitc mixtures", Ind. Eng. Chem. Res., vol. 40, pp. 3749-3756, July 2001. 
[54] Nikolov, A., Rostovsky, I., Nugteren, H., "Geopolymer materials based on natural zeolite", Case studies in construction materials, vol. 6, pp. 198-205, March 2017.

[55] Duxson, P., Provis, J. L., "Designing precursors for geopolymer cements", Journal of Am. Ceram. Soc., vol. 91, pp. 3864-3869, Nov. 2008.

[56] Casey, W. H., Westrich, H. R., Holdren, G.R., "Dissolution rates of plagioclase at $\mathrm{pH}=1$ and 3", Am. Mineral, vol. 76, pp. 168-173, Jan. 1991.

[57] Davidovits, J., Geopolymer-Chemistry \& Application, 4th ed., Institute Geopolymere, Saint-Quentin, France, Nov. 2015.

[58] Jin, M., Zheng, Z., Sun, Y., Chen, L., Jin, Z., "Resistance of metakaolin-MSWI fly ash-based geopolymer to acid and alkaline environments", Journal of Non-Crystalline Solids, vol. 450, pp. 116122, Aug. 2016.

[59] Bhutta, A., Borges, P. H. R., Zanotti, C., Farooq, M., Banthia, N., "Flexural behavior of geopolymer composites reinforced with steel and polypropylene macro fibers", Cement and Concrete Composites, vol. 80, pp. 31-40, March 2017.

[60] Sanjayan, J. G., Nazari, A., Pouraliakbar, H., "FEA modelling of fracture toughness of steel fibre-reinforced geopolymer composites", Materials and Design, vol. 76, pp. 215-222, March 2015.

[61] Khan, M. I., Azizli, K., Sufian, S., Man, Z., "Sodium silicate-free geopolymers as coating materials-Effects of $\mathrm{Na} / \mathrm{Al}$ and water solid ratios on adhesion strength", Ceramics International, vol. 41, pp. 2794-2805, Okt. 2014.

[62] Abdel-Ghani, N. T., Elsayed, H. A., AbdelMoeied, S., "Geopolymer synthesis by the alkali-activation of blastfurnace steel slag and its fireresistance", Housing and Building National Research Center, http://dx.doi.org/10.1016/j.hbrcj.2016.06.001, pp. 1-6, June 2016.

[63] Karakoc, M.B., Turkmen, I., Maras, M. M., Kantarci, F., Demirboga, R., "Sulfate resistance of ferrochrome slag based geopolymer concrete", Ceramics International, vol. 42, pp. 1254-1260, Sept. 2015

[64] Sakkas, K., Sofianos, A., Nomikos, P., Panias, D., "Behaviour of passive fire protection K-Geopolymer under successive severe fire incidents", Materials, vol. 8, pp. 6096-6104, Sept. 2015.

[65] Sadek, D. M., "Effect of cooling technique of blast furnace slag on the thermal behavior of solid cement bricks", Journal of Cleaner Production, vol. 79, pp. 134-141, May 2014.

[66] Chiang, Y. W., Santos, R. M., Elsen, J., Meesschaert, B., Martens, J. A., Gerven, T. V., "Towards zero-waste mineral carbon sequestration via two-way valorisation of ironmaking slag", Chemical Engineering Journal, http://dx.doi.org/10.1016/j/cej.2014.03.104, March 2014.

[67] Zhang, H. Y., Kodur, V., Qi, S. L., Cao, L., Wu, B., "Development of metakaolin-fly ash-based geopolymers for fire resistance applications", Construction and Building Materials, vol. 55, pp. 38-45, Feb. 2014.

[68] Roviello, G., Ricciotti, L., Ferone, C., Colangelo, F., Tarallo, O., "Fire resistant melamine based organic-geopolymer hybrid composites", Cement \& Concrete Composites, vol. 59, pp. 89-99, March 2015.

[69] Rickard, W. D. A., Vickers, L., Riessen, A. V., "Performance of fibre reinforced, low-density metakaolin geopolymers under simulated fire conditions", Applied Clay Science, vol. 73, pp. 71-77, Nov. 2012

[70] Suksiripattanapong, C., Ang-Kua, T., Arulrajah, A., Maghool, F., Horpibulsuk, S., "Strength and microstructure properties of spent coffee grounds stabilised with rice husk ash and slag geopolymers", Construction and Building Materials, vol. 146, pp. 312-320, Apr. 2017.

[71] Zhang, Z., Provis, J. L., Reid, A., Wang, H., "Mechanical, thermal insulation, thermal resistance, and acoustic absorption properties of geopolymer foam concrete", Cement \& Concrete Composites, vol. 62, pp. 97-105, June 2015.

[72] Yan, B., Duan, P., Ren, D., "Mechanical strength, surface abrasion resistance and microstructure of fly ash-metakaolin-sepiolite geopolymer composites", Ceramics International, vol. 43, pp. 1052 1060, Oct. 2016.

[73] Zeng, S., Wang, J., "Characterisation of mechanical and electrical properties of geopolymers synthesised using four locally available fly ashes", Construction and Building Materials, vol. 121, pp. 386-399, June 2016.

[74] Rickard, W. D. A., Riessen, A. V., "Performance of solid and cellular structured fly ash geopolymers exposed to a simulated fire", Cement \& Concrete Composites, vol. 48, pp. 75-82, Sept. 2013.

[75] Martin, A., Pastor, J. Y., Palomo, A., Jumenez, F., "Mechanical behaviour at high temperature of alkali-activated aluminosilicates (geopolymers)", Construction and Building Materials, vol. 93, pp. 1188-1196, May 2015.

[76] Cioffi, R., Maffucci, L., Santoro, L., "Optimisation of geopolymer synthesis by calcination and polycondensation of a kaolinitic residue", Resources, Conservation and Recycling, vol. 40, pp. 27-38, Dec. 2003.

[77] Brown, W. H., Poon, T., Introduction to Organic Chemistry, International Student Version, Fifth Edition, John Wiley \& Son, Inc. 2014.

[78] Putri, R. E., Yahya, A., Adam, N. M., Aziz, S. A., "Correlation of moisture content to selected mechanical properties of rice grain samples", International Journal on Advanced Science Engineering Information Technology, vol. 5(5), pp. 264-267, ISSN 2088-5334, http://dx.doi.org/10.18517/ijaseit.5.5.561, 2015.

[79] Gharzouni, A., Vidal, L., Essaidi, N., Joussein, E., Rossignol, "Recycling of geopolymer waste: influence on geopolymer formation and mechanical properties", Materials and design, vol. 94, pp. 221229, 2016

[80] Glid, M., Sobrados, I., Rhaiem, H. B., Sanz, J., Amara, A. B. H "Alkaline activation of metakaolinite-silica mixtures: role of dissolved silica concentration on the formation of geopolymers", Ceramics International, vol. 43, pp. 12641-12650, 2017.

[81] Greiser, S., Sturm, P., Gluth, G. J. G., Hunger, M., Jager, C., "Differentiation of the solid-state NMR signals of gel, zeolite phases and water species in geopolymer-zeolite composites", Ceramics International, vol. 43, pp. 2202-2208, 2017

[82] Minelli, M., Papa, E., Medri, V., Miccio, F., Benito, P., Doghieri, F., Landi, F., "Characterisation of novel geopolymer-zeolite composites as solid absorbents for $\mathrm{CO}_{2}$ capture", Chemical Engineering Journal, vol. 341 , pp. 505-515, 2018

[83] Khalid, H. R., Lee, N. K., Park, S. M., Abbas, N., Lee, H. K. "Synthesis of geopolymer-supported zeolites via robust one-step method and their absorption potential", Journal of Hazardous Material, vol. 353, pp. 522-533, 2018

[84] Lee, N. K., Khalid, H. R., Lee, H. K., "Differentiation of the solidstate NMR signals of gel, zeolite phases and water species in geopolymer-zeolite composites", Microporous and Mesoporous Materials, vol. 229, pp. 22-30, 2016

[85] Papa, E., Medri, V., Amari, S., Manaud, J., Benito, P., Vaccari, A., Landi, E., "Zeolite-geopolymer composite materials: production and characterisation", Journal of Cleaner Production, vol. 171, pp. 76-84, 2018 